\title{
Recent Challenges of the Ecosystems Services Approach from an Interdisciplinary Point of View
}

\section{Aktuelle Herausforderungen des Ansatzes der Ökosystemdienstleistungen aus interdisziplinärer Sicht}

https://doi.org/10.2478/rara-2019-0055

Eingegangen: 11. April 2019; Angenommen: 8. Oktober 2019

\begin{abstract}
The ecosystem services approach has attracted tremendous attention from policymaking, planning and interdisciplinary sciences over the last decades. Despite its broad acknowledgement worldwide, there are a number of well-known conceptual and methodological limitations that impair its use and practical operationalisation. A brief discussion of these deficits is conducted from the integrated perspective of natural and social sciences. The paper then critically addresses the question of whether and to what extent the diversity, complexity and hybridity of the human-nature context should be shaped into a uniform scheme, disregarding the differing scales of the social, economic and ecological processes, functions and the trade-offs between them.
\end{abstract}

Keywords: Ecosystem services, complexity, interdisciplinarity, natural sciences, sociology, criticism, conflict

Kurzfassung: Das Konzept der Ökosystemdienstleistungen hat in den letzten Jahrzehnten in beachtlichem Maße Eingang in die politische Entscheidungsfindung, die räumliche Planung und in die interdisziplinär ausgerichteten Wissenschaftsdisziplinen gefunden. Trotz seiner weltweiten Wahrnehmung und verbreiteten Anerkennung weist dieser Ansatz bekanntermaßen eine Reihe konzeptioneller und methodische Defizite auf, die seine Anwendung und Operationalisierbarkeit erschweren. Neben einer kurzen Diskussion der aus einer integrativen natur- und sozialwissenschaftlichen Perspektive heraus beleuchteten Limitierungen wirft der vorliegende Beitrag die Frage auf, ob und inwieweit es sinnvoll ist, die Vielfalt, Komplexität und Hybridität von Mensch-Umwelt-Systemen in ein einheitliches Bewertungsschema einzupassen und dabei die verschiedenen Ebenen der sozialen, wirtschaftlichen und ökologischen Prozesse, Funktionen und Zielkonflikte zu ignorieren.

Schlüsselwörter: Ökosystemdienstleitungen, Komplexität, Interdisziplinarität, Naturwissenschaften, Soziologie, Kritik, Konflikt

\footnotetext{
*Corresponding author: Prof. Dr. Dr. Olaf Kühne, Eberhard-Karls-Universität Tübingen, Geographisches Institut, Rümelinstraße 19-23, 72070 Tübingen, Deutschland, E-Mail: olaf.kuehne@uni-tuebingen.de

Prof. Dr. Rainer Duttmann, Christian-Albrechts-Universität zu Kiel, Geographisches Institut, Ludewig-Meyn-Straße 14, 24098 Kiel, Deutschland
} 


\section{Introduction}

Over the past decade and a half, the concept of ecosystem services has developed into a very widespread approach in environmental sciences and environmental policy, addressing human dependencies on the environment. The concept of ecosystem services aims at making human society aware of the services provided by nature and subjecting them to systematic consideration. At the same time, classical concepts such as 'natural space potentials' or 'landscape functions' have largely been squeezed out of the discussion. With the "Millennium Ecosystem Assessment" (MEA 2005) commissioned by the United Nations in 2001, as well as "The Economics of Eco-systems and Biodiversity" (TEEB 2010) and the "Intergovernmental Science-Policy Platform on Biodiversity and Ecosystem Services" (IPBES; see Díaz/Demissew/Carabias et al. 2015), these have been further differentiated (see e.g. Kirchhoff 2019a; Kirchhoff $2019 b)$. What is remarkable about the scientific and political discussion of ecosystem services is its focus on an ecosystemic perspective on the one hand and on approaches in environmental economics on the other. In comparison to physiocentric concepts (in which 'nature' is considered to have an intrinsic value) or theocentric positions (in which 'nature' is to be protected as God's work), the ecosystem services approach is based on an anthropocentric attitude in which the protection of 'nature' is justified on the basis of its serviceability to humans.

The approach has already been critically assessed. In particular the integration (and thus subordination) of cultural values into the ecosystem services logic has been questioned (e.g. Chan/Satterfield/Goldstein 2012; Fish/Church/Winter 2016; Kirchhoff 2018; Kirchhoff 2019b; strongly condensed: Kirchhoff 2012) and the pecuniary relation or basic 'neoliberal' attitude scrutinised (e.g. Kosoy/Corbera 2010; Gómez-Baggethun/RuizPérez 2011; Leibenath 2017). An overview of criticism and counterarguments can be found in Schröter, van der Zanden, van Oudenhoven et al. (2014).

This paper summarises and correlates essential critiques of the core of the ecosystem services approach from both a natural science and a sociological perspective - an approach to the topic of ecosystem services that has not previously been pursued. Potentials for further research are identified from this specific reference. In the following, the main critiques from the perspective of social and environmental sciences will be discussed, considering the current limitations and future challenges to an improved representation of the spatio-temporal dynamics of socio-environmental systems (Sections 3 and 4). First, however, the main features of the concept are presented (Section 2).

\section{The main features of the approach}

The underlying understanding of ecosystems is positivist: "An ecosystem is a dynamic complex of plant, animal, and microorganism communities and the nonliving environment interacting as a functional unit" (MEA 2005: V). An ecosystem is thus seen as a functional entity 'really existing' outside human consciousness. These units provide certain 'services' for humans. According to the MEA (2005), a distinction is made between four classes of ecosystem services: first, the basic or supporting services (as the foundation for the other ecosystem services, e.g. photosynthesis or soil formation); second, the supply services (like the provision of raw materials such as food or unpolluted water); third, the regulatory services (e.g. the mitigation of flood hazards by forests); fourth, the cultural services (such as the importance of nature for human recreation). Within the framework of the ecosystem services concept, the burden on the natural environment is transformed into a quantifiable unit, which indicates the human burden caused by the burden on the environment. Indexing is preferably (but not necessarily) carried out in monetary units. The basis of this approach is the classical environmental-economic consideration, which expresses itself in the fact that in the case of the aggrieved parties the deprivation of scarce alternative goods takes place in exchange for the thus scarce good the 'natural environment'. In the economic sense, costs in cost units represent the withdrawal of alternative goods valued in monetary units. This turns the change in the natural environment into a cost problem, which makes it possible for economic entities suffering environmental damage to carry out a process in accordance with economic rationality (see e.g. Costanza 1991; Cropper/Oates 1992).

The concept of ecosystem services is intended to contribute to reducing the external effects, i.e. undesirable, mostly negative side effects, of economic agents' activities. These result from the fact that certain uses of the natural environment are not regulated by markets and that it seems opportune for rational economic operators to use unpriced aspects of the environment as extensively as possible (Lee 2004), since these are 
"neither perceived by producers nor consumers in an appropriate manner, but are rather taken for granted by large sections of the population" (Hansjürgens/SchröterSchlaack 2012: 17).

\section{Challenges and limitations from a natural science perspective}

\subsection{Main outlines of the concept of ecosystem services}

As mentioned in the introduction, today the concept of ecosystem services variably shapes thinking and action in environmental policy, environmental planning and environmental management oriented towards the principles of sustainability. Against the background of increasing environmental pollution and a loss of biodiversity, the ecosystem services concept should not only contribute to increased social appreciation of the vital services provided by the ecosystem. Rather, the ecosystem itself should also provide an orientation framework for (participatory) planning and decisionmaking processes with its own interdisciplinary and transdisciplinary approach.

The ecosystem services concept is based on the principle that human well-being depends decisively on the functioning of ecosystems and the services they provide. It is intended to help record the (free) services provided by nature and to evaluate them in terms of their significance for people - if necessary, also in monetary terms (Grunewald/Bastian 2014). Its aim is to relate the ecosystem services provided naturally to the social/ economic needs and benefits of these services.

Ecosystem services are the interface between the supply of natural services, the ecological baselines, on the one hand, and social demand and utilisation on the other. According to the definition given by Costanza, d'Arge, de Groot et al. (1997), ecosystem services are those ecological properties, functions and processes that directly or indirectly contribute to human well-being. Only these are regarded as ecosystem services. It is irrelevant whether the processes and functions involved consciously or unconsciously, directly or indirectly influence human well-being (Costanza/de Groot/Braat et al. 2017). Services provided by ecosystems that have no social or economic benefit are not considered ecosystem services.
Ecosystem services cannot be equated with 'ecosystem functions'. The latter generally refer to the biotic and abiotic components of the system and their interactions with each other, regardless of whether they are beneficial to human well-being or not. They are the prerequisite for the provision of services which are considered useful and beneficial to human beings. De Groot, Wilson and Boumans (2002: 393) define ecosystem functions as "the capacity of natural processes and components to provide goods and services that meet human needs directly or indirectly". The individual functions are to be understood as the result of natural processes, which in turn result from complex material and energetic interactions between the biotic and abiotic ecosystem components. Boyd and Banzhaf (2007) describe these ecosystem functions as intermediate services of natural processes, which are to be distinguished from the 'final' ecosystem services as defined above.

With the aim of sharpening and operationalising the ecosystem services concept terminologically and methodologically, numerous interdisciplinary and transdisciplinary frameworks and order schemata (e.g. Haines-Young/Potschin 2009; TEEB 2010; HainesYoung/Potschin 2018) have emerged and been controversially discussed (see in detail Bastian/Haase/ Grunewald 2012; Braat/de Groot 2012; Costanza/de Groot/Braat et al. 2017; Potschin-Young/Haines-Young/ Görg et al. 2018). A uniform methodology for quantifying, evaluating and spatially mapping ecosystem services does not exist.

Approaches to assessing the functions and potentials of landscape ecosystems are not new in principle (Grunewald/Bastian 2014) and were not 'invented' only as part of the ecosystem services concept. They look back on a long history, especially in German-speaking geography and landscape ecology. The works of Marks, Müller, Leser et al. (1989), Haase (1991), Bastian and Schreiber (1994), Bastian and Steinhardt (2002) and Grunewald and Bastian (2013a) provide overviews on this. Marks, Müller, Leser et al. (1989) already compiled a collection of methods for the assessment of numerous functions of landscape ecosystems and the landscape budget without, however, actually developing a theorybased concept. The capacity of landscape ecosystems to provide important services for all living beings is referred to as the capacity of the landscape budget (Marks/Müller/Leser et al. 1989). The perspective of this methodology ideally goes beyond the more humancentred and utilitarian horizon of the ecosystem services concept, since it also recognises the 'value' of the 
individual services of the landscape budget for the flora and fauna. Mosimann, Köhler and Poppe (2001) draw on the theoretical pre-consideration that the development of functionally diverse landscapes in line with sustainability objectives requires an optimal distribution of areas with different use intensities on the one hand and protected areas on the other, in order to meet social demands and the habitat needs of a rich flora and fauna. They therefore propose a practice-oriented methodology for deriving process-based models for functionally diverse landscapes ('multifunctional landscapes'). The knowledge-based landscape models generated by this methodology aim, among other things, at the long-term preservation of the functions of use, protection and regulation, and at the minimisation of possible conflicts of use. The various landscape functions are no longer assigned only to the areas arranged discreetly next to each other and characterised by the same structural properties but are also viewed in a spatial and procedural context. Thus, the spatial units constituting the landscape mosaic are perceived as "budget-related functional units ('process units')" (Mosimann/Köhler/Poppe 2001: 37), which are integrated into a lateral process structure. The involvement of neighbourhood effects between the respective process units not only allows the mapping of spatial function overlaps, but also the transition from an isolated consideration of individual functions related to discrete area units to a context-oriented, spatially connective mapping of the multifunctional landscape structure.

\subsection{Conceptual deficits}

Despite its widespread appreciation, highly impressive research activities worldwide, work on the operationalisation of the approach and the quantification of ecosystem processes, functions and services (Costanza/de Groot/Braat et al. 2017), the concept has a number of limitations. These go beyond the oftenvoiced criticism of the anthropocentric nature of the ecosystem services concept, and need to be part of the future research agenda. Such limitations include the large variety of terms and definitions used in different disciplines, and the lack of universally accepted evaluation methods and sufficiently robust simulation models. In addition, understanding of the processes that are effective on different spatial and temporal scales and are ultimately involved in the realisation of ecosystem services (Birkhofer/Diehl/Andersson et al. 2015; Lavorel/ Bayer/Bondeau et al. 2017) is often still poor. Based on a quantitative evaluation of a random sample of the publications on ecosystem services research listed in the ISI Web of Knowledge ${ }^{1}$ between 1996 and 2016, Lautenbach, Mupepele, Dormann et al. (2019) identify the following 'blind spots', among others:

- Validity of the data sources and models used in social-ecological evaluations, including (i) a limited representation of non-linearities and feedback effects governing the interactions inside and between human-environmental systems, (ii) a restricted representation of the spatio-temporal variability of these systems and (iii) a lack of verification of the prediction results by testing them against independent data. The same limitations hold for most spatial decision-support tools used for the spatially explicit assessment of ecosystem services. Despite all the achievements attained in quantitative ecosystem services assessment (e.g. Bagstad/ Semmens/Waage et al. 2013), Rieb, ChaplinKramer, Daily et al. (2017: 820) emphasise that most of these tools "are missing crucial components of the complexity needed to fully answer the question of when, where and how much nature matters to the resilient provision of ES [ecosystem services] and to human well-being".

- Analysis of trade-offs among the different ecosystem services and the beneficiaries of these services, respectively. As stated by Howe, Suich, Vira et al. (2014), Martinez-Harms, Bryan, Balvanera et al. (2015) and Lautenbach, Mupepele, Dormann et al. (2019), most of the trade-off studies apply rather simple (static) approaches, like correlation or map overlay analyses of selected ecosystem services, while more complex ones that also consider interactions and interdependences between certain ecosystem services and their dynamics are still rare. Moreover, according to Howe, Suich, Vira et al. (2014), the majority of ecosystem services studies relate to individual services, while understanding trade-offs necessitates considering several ecosystem services in/of the same system. To gain a better theoretical understanding of the relationships between the various ecosystem services, and the trade-offs and synergies among them, Bennett, Peterson and Gordon (2009) suggest a typology to consider the drivers, responses and interactions between the various services; this has the potential to overcome some of the aforementioned limitations.

1 https://webofknowledge.com (19.08.2019). 
- Consideration of the off-site effects and related scale transitions needed for a cross-border assessment of ecosystem services that flow from the sending to the receiving socio-ecological systems (Schröter/ Koellner/Alkemade et al. 2018) on the one hand. And better understanding of distance or telecoupling effects between areas that are connected via transports of energy, water, solid matter and information on the other hand. Because the offstage effects of place-based ecosystem services can negatively affect neighbouring or distant ecosystems and their biodiversity, Pascual, Palomo, Adams et al. (2017: 1) suggest "that off-stage ecosystem service burdens should be incorporated in ecosystem service assessments, as for instance conducted by the Intergovernmental Platform on Biodiversity and Ecosystem Services (IPBES) and the Intergovernmental Panel on Climate Change".

- Although some studies exist that include the flows of provisioning, regulating and cultural ecosystem services at different spatial scales (e.g. Lopéz-Hoffman/Varady/Flessa et al. 2010, García-Nieto/García-Llorente/Iniesta-Arandia et al. 2013; Liu/Yang/Li 2016), most ecosystem service assessments do not yet consider the cross-scale linkages of ecosystem services flows (e.g. Pascual/ Balvanera/Díaz et al. 2017; Lautenbach/Mupepele/ Dormann et al. 2019). To overcome this 'blind spot', Schröter, Koellner, Alkemade et al. (2018) suggest a conceptual framework that defines the components of telecoupled socio-ecological systems and interregional ecosystem services flows, including the relationships between the drivers and impacts of sent and received ecosystem services, and also considering the co-production of ecosystem services through anthropogenic inputs.

Table 1 gives an overview of the frequently mentioned limitations of the ecosystem services concept.

Although the significance of the services covered by the ecosystem services concept for human society is beyond question, the anthropocentric and utilitarian approach of the concept has been the subject of critical discussion since its inception. However, there are good and comprehensible reasons for opposing lines of argumentation (see the detailed description in Schröter/van der Zanden/van Oudenhoven et al. 2014). Since humans are ultimately responsible for the globally observable degradation and loss of ecosystems and biodiversity, it naturally makes sense to address potential losses, possibly underpinned by monetary valuations. On the other hand, ecosystems perform a variety of functions for other living creatures without directly or indirectly benefiting humans, but benefiting the functioning of natural ecosystems themselves. The consideration of system-immanent 'events' such as fire, floods, storm events and cyclical epidemics, which are essential for the development and existence of numerous natural ecosystems but are also associated with negative effects for human 'well-being', are often neglected in the evaluation of ecosystem services.

Lyytimäki and Sipilä (2009) and Dunn (2010) criticise the positivist approach of the ecosystem services concept, as it focuses on the services of the natural environment that are considered valuable for human well-being, while the adverse social and economic effects of natural ecosystems, known as ecosystem disservices, are often ignored or not explicitly named as such (cf. Shapiro/ Báldi 2014). Sandbrook and Burgess (2015) therefore propose integrating disservices into existing ecosystem services (conceptual frameworks) approaches with the aim of correlating positive services for well-being with ecosystem processes that are perceived negatively from a social point of view. This should give a more complete picture of how people benefit or suffer costs from nature (Sandbrook/Burgess 2015).

The term 'ecosystem disservices' can be only understood against the background of the ecosystem services concept. From an ecological and natural science perspective however, this term seems questionable since there are no 'disservices' in ecosystems unaffected by humans. Under natural conditions, disturbances often contribute to the preservation of these systems, their biophysical diversity and ecological resilience (e.g. Seidl/ Thom/Kautz et al. 2017). According to Montagne-Huck and Brunette (2017: 2), natural disturbances form an integral part of natural ecosystem health and natural ecosystem functioning, where catastrophic events can lead to severe changes in the natural environment (e.g. biodiversity, weather and climate conditions at different spatial scales, carbon budget) and in the various kinds of nature use and appreciation. Actually, it is unclear how these naturally occurring short-time events and their multiple effects on humans and on the environment can be integrated into the ecosystem services concept and ultimately evaluated in monetary terms. This may be illustrated by the example of fire regimes, which are characteristic of the dynamics of North America's natural yellow pine forests (Hutto 2008). The forest fires were considered negative for humans, their material goods and forestry use, so smaller fires were suppressed leading to decreasing diversity of the spatial mosaic 
Table 1: Commonly mentioned shortcomings of the ecosystem services concept

\begin{tabular}{|c|c|c|}
\hline & Limitations & References \\
\hline Conceptual & $\begin{array}{l}\text { Definitory blurriness, inconsistent use of central terminology, different and } \\
\text { inconsistent conceptualisations of the ecosystem services approach }\end{array}$ & $\begin{array}{l}\text { Grunewald/Bastian (2013c: 15); La } \\
\text { Notte/D’Amato/Mäkinen et al. (2017: } \\
\text { 393) }\end{array}$ \\
\hline $\begin{array}{l}\text { Methodological/ } \\
\text { scientific }\end{array}$ & $\begin{array}{l}\text { Lack of uniformly applicable and standardised methods for the } \\
\text { assessment/evaluation/modelling/mapping of ecosystem functions and } \\
\text { ecosystem (services) with simultaneous method diversity, prevalence of } \\
\text { simple (static) methods and empirical models for estimating ecosystem } \\
\text { services }\end{array}$ & $\begin{array}{l}\text { Lavorel/Bayer/Bondeau et al. (2017: } \\
\text { 242) }\end{array}$ \\
\hline
\end{tabular}

Lack of uniform criteria for spatial delimitation of ecosystems at different Grunewald/Bastian/Syrbe (2013: $61 \mathrm{ff}$.) scales, lack of a system for the typification of ecosystems

Lack of consideration of cross-scale effects, spatial connectivity, neighbourhood effects, and remote effects of (locally) provided ecosystem services
Seppelt/Dormann/Eppink et al. (2011: 634); Grunewald/Bastian/Syrbe (2013: $61 \mathrm{ff}$.$) ; Bennett/Cramer/Begossi et al.$ (2015: 79)

Little treatment of the spatial and temporal dynamics of ecosystems and Grunewald/Bastian/Syrbe (2013: 60) the dependent changes of the corresponding ecosystem services

Lack of good technical practice for validating models and quantifying model errors ('uncertainties')

Limited data availability, poor data quality, and low temporal and spatial resolution of the available (geo) data

Limitations in the capture/treatment of 'uncertainties' in the modelling of ecosystem functions and ecosystem services and the indicators used here

Incomplete knowledge of the interaction of social and ecological system components and its significance for the provision of ecosystem services, insufficient understanding of the human contribution to the provision of possible ecosystem services (e.g. biomass production in agroecosystems) and the influence of management on the temporal changes of ecosystem functions and ecosystem services, uncertainties in the delimitation of the direct and indirect contributions of ecosystems to the individual ecosystem services

Little or no knowledge of the significance of biodiversity for the provision of individual ecosystem services, incomplete knowledge about the influence of biodiversity on the functions of ecosystems of different space 78) and time scales

Deficits in the understanding of temporal and spatial relationships in the TEEB (2010:4) provision of ecosystem services
Lavorel/Bayer/Bondeau et al. (2017: 255)

Lavorel/Bayer/Bondeau et al. (2017: 255)

Costanza/de Groot/Braat et al. (2017: 11); Müller/Burkhard (2012: 28)

Grunewald/Bastian (2013c: 15); Lavorel/Bayer/Bondeau et al. (2017: 242); Costanza/de Groot/Braat et al. (2017: 14); Bennett/Cramer/Begossi et al. (2015: 77)

Grunewald/Bastian (2013b: 3); Bennett/Cramer/Begossi et al. (2015: of different population ages and succession stages formed under natural conditions. At the same time, restrictive fire management led to the accumulation of fuel material from dead and dry organic matter, increasing stock densities and the development of undergrowth in the form of storeys. The consequences of misunderstanding the regulatory functions of fire are now evident in many places (such as the devastating bush and forest fires in California around late summer and autumn 2018). This has significantly more negative and spatially extensive effects on human well-being than would probably have been the case if the fire-related small-scale heterogeneity and diversity of forest stands had been preserved (e.g. Rogers 1996; Donovan/ Brown 2007; for a more detailed view on the role of disturbances in natural systems in general see Battisti/ Poeta/Fanelli 2016). However, the question of the role of natural systems and natural patch dynamics for the long-term provision of ecosystem services is difficult to address, especially since natural disturbances in ecosystems organised by humans are mostly prevented or combated at an early stage. 
Currently, a separation between the human and the natural parts of the individual ecosystem services is hardly possible. The influence of human activities on the provision of ecosystem services - the co-production of ecosystem services - is only understood to a limited extent (Bennett/Cramer/Begossi et al. 2015). Moreover, increased scientific knowledge from integrated ecological and economic research is needed in order to involve both the small-scale and short-term dynamics of ecosystems in a more systemic assessment of ecosystem services provision, the role of the spatial composition of the different stages in ecosystem development and their respective small-scale heterogeneity.

In view of the fact that natural ecosystems, for example in Europe, occupy only a comparatively small proportion of the land area, at this point it seems reasonable to ask which of the 'ecosystem services' can still be regarded as 'natural' at all in an environment largely organised by humans. Numerous basic services, but also regulation and supply services under agricultural use, are controlled by management and management intensity, whereby a clean methodological separation of the natural and human parts of the realisation of these services is known to be difficult (see Grunewald/Bastian 2013c: 15).

\subsection{Knowledge deficits}

The complex process-related connectivities between ecological and socio-economic system components, especially in ecosystems directly influenced and shaped by humans, such as urban ecosystems, forest ecosystems and agro-ecosystems are still poorly understood. For example, agricultural land alone accounts for about $37 \%$ of the world's total land area (UBA 2013: 12). One third of this is used for arable farming. These areas are responsible for the provision of numerous basic and utility services and influence human well-being in many ways. At the same time, it is well known that these (eco-) systems are also, as a result of an increasing demand for plant and animal raw materials, experiencing an increasing loss of biological and structural diversity and natural soil fertility.

While the decline in natural soil fertility in intensively farmed agroecosystems can be compensated to a certain extent, natural functional diversity and biological diversity are gradually declining (see Birkhofer/Diehl/ Andersson et al. 2015; Techen/Helming 2017). The maintenance of production services (provisioning services) is thus countered by an increasing degradation of ecosystem basic services (supporting services) such as material transformation services and regulatory services (regulating services) like the control of surface runoff and soil erosion or the sequestration of $\mathrm{CO}_{2}$. These effects, known as trade-offs, have also only been studied to a limited extent to date. Nelson, Mendoza, Regetz et al. (2009) describe one of the few approaches for modelling trade-offs of selected ecosystem services on the landscape scale.

Considerable knowledge deficits also concern the long-term effects of different land use and management systems as well as the effects of land-use changes on the respective ecosystem functions and the ecosystem services provided by them. The same applies to the spatio-temporal dynamics of the mutually influencing anthropogenic, natural and semi-natural processes and functions (cf. Bennett/Cramer/Begossi et al. 2015). In addition, the process-related connections between the service providing areas and the "effective areas", i.e. the "service benefiting areas" and the scale transitions of the service-producing functions are largely unexplored (Grunewald/Bastian/Syrbe 2013: 59).

An improved applicability of the ecosystem services approach in ecosystems that have been strongly anthropogenically modified, such as agricultural systems, requires a more comprehensive (Birkhofer/ Diehl/Andersson et al. 2015) and system-oriented perspective, including greater consideration of the socio-economic and technological driving forces that mainly control the dynamics of these systems (e.g. farm management and soil tillage practices). An integrated socio-ecological conceptual framework for the servicebased management of agro-ecosystems has been suggested by Lescourret, Magda, Richard et al. (2015), showing how management practices can govern the provision of multiple services. Another interesting approach for a context-oriented and system-analytical examination of the multiple cause-effect relationships in anthropogenically modified and utilised ecosystems is offered by the DPSIR (driving force - pressure - state - impact - response) concept, designed by Smeets and Weterings (1999). This conceptual framework relates the driving forces via the structural and functional changes (pressures) caused by them to the resulting state of the bio-physical system components, functions and structures. Müller and Burkhard (2012) give an example of the link between the DPSIR approach and the ecosystem service cascade designed by Haines-Young and Potschin (2010). Accordingly, ecosystem services and the underlying ecosystem properties, structures and processes are seen here as part of the adaptive DPSIR 
cycle (Müller/Burkhard 2012). In this way, the spatial and temporal dynamics of the ecosystem services can be put into a causal relationship with the socio-economic and technological driving forces and an improved systemic understanding of human-environment-interactions can be achieved and quantitatively described by means of suitable indicators. However, here too, further research efforts are needed to quantify the temporally and spatially variable effects of the different driving forces on the natural functioning of agricultural ecosystems and the services they provide.

Knowledge of the interdependent behaviour of the coupled socio-economic and ecological system components, based on reliable data and research results, is ultimately essential in order to move from an 'ex post' to an 'ex ante' view of the ecosystem services and is indispensable for forward-looking, i.e. future-oriented ecosystem services management (e.g. Kubiszewski/ Costanza/Anderson et al. 2017).

In view of the increasing pressure on a wide variety of ecosystems and declining biodiversity (UBA 2018), the protection aspect of the ecosystem services concept is neglected. In this way, the concept leaves open the question of how the protection and conservation of ecosystems and their services should be measured in concrete terms. Although it is clear that the protection of biological diversity is as essential for human wellbeing as the preservation of natural resources and the functional diversity of ecosystems, there is no "strategy for the determination of management thresholds" (Müller/ Burkhard 2012: 29) just as there is no definition of uniform - scientifically justified - objectives for the sustainable use of the ecosystem services. One way of taking equal account of the use and protection aspects in an assessment of ecosystem services could be to integrate the UN Sustainable Development Goals (SDGs) ${ }^{2}$ into the ecosystem services concept (cf. Kubiszewski/Costanza/ Anderson et al. 2017; Wood/Jones/Johnson et al. 2018).

\subsection{Research needs}

Taking the aforementioned limitations as challenges for future research activities, preferential attention should be given to a deeper integration of human and physical drivers into socio-ecological systems modelling and ecosystem services assessment, including spatial and temporal dynamics of drivers, impacts and system

2 See https://www.un.org/sustainabledevelopment/sustainabledevelopment-goals/ (20.08.2019). responses at different scales. In order to improve given ecosystem services modelling tools, Rieb, ChaplinKramer, Daily et al (2017) identified three crucial research frontiers: firstly, understanding of the spatiotemporal dynamics of ecosystem services and the interactions between ecosystem services; secondly, understanding of the linkages between biophysical ecosystem services provision and human wellbeing; and thirdly, understanding of the role of different kinds of natural and non-natural capital to substitute or enhance ecosystem services provision. The latter point is important to quantify the contributions of humans and nature to ecosystem services and thus to finally include co-production of ecosystem services by ecological and social systems in ecosystem services assessments (cf. Bennett/Cramer/Begossi et al. 2015). As stated by Lautenbach, Mupepele, Dormann et al. (2019), not including anthropogenic modifications of ecosystems in ecosystem services assessments may lead to ineffective or counterproductive decision-making. This holds especially for agro-ecosystems where biomass and food production depend on soil and land management practices. An integrated socio-ecological approach for the service-based management of agro-ecosystems that considers the multiple relationships among the various services, the major impacts of agricultural management on these and the diverse actors involved as well, has been presented by Lescourret, Magda, Richard et al. (2015). However, the development of models that explicitly integrate the effects of different management impacts into multiple agro-ecosystem service assessment will be a main task for future research. The reliability of the modelling results depends on the validity of the data and models employed. Lautenbach, Mupepele, Dormann et al. (2019) emphasise the necessity to develop applicable strategies for model validation and error assessment to identify, quantify and communicate uncertainties that should be included in future ecosystem services studies.

A further need in ecosystem services research lies in the enlightenment of the off-site or stage-effects of place-based ecosystem management on biodiversity and ecosystem services, as has been pointed out by Pascual, Palomo, Adams et al. (2017) and in exploring the trade-offs and synergies among the various ecosystem services as outlined by Bennett, Peterson and Gordon (2009). According to Bennett, Cramer, Begossi et al. (2015) research in this field should not only expand on the trade-offs and synergies but also focus on the interactions between non-provisioning services. 


\section{The social scientific limitations of the approach}

After focusing on the limitations of the concept of ecosystem services from the perspective of the natural sciences, the following is a critique from the point of view of social science informed by systems theory. From a systems theoretical perspective, it is possible to examine the impact of specific societal subsystems, both on each other and in relation to the non-social environment. Social systems theory postulates that society is subdivided into subsystems that assume certain tasks exclusively for society (among many: Parsons 1951; Luhmann 1984; Luhmann 1986; Luhmann 2002). For example, it is the task of the social subsystem economy to supply society with goods and services, that of science to achieve secure knowledge, that of politics to steer society, that of the mass media to provide society with up-to-date information, etc. Each of these subsystems is only able to observe its environment (as well as itself) according to its own logic, the economy subsystem observes according to the question of whether money can be earned, the politics subsystem asks if power can be won, science focuses on whether knowledge can be generated, and the mass media subsystem observes whether file information can be created or distributed. In contrast to the other systems, mass media - currently since the development of Web 2.0 also electronic platforms - are able to address society as a whole. This enables these media to create maximum irritation in society, which forces other social subsystems to address these issues (e.g. politics on climate change and its consequences) (Luhmann 1993). Mass media communication is largely moral. This moralisation hits the social subsystem of the economy, which was (and is) accused of seeing the world only as an economic resource and of being blind to the 'intrinsic values' of the natural environment, cultures, local peculiarities and much more (cf. Luhmann 1980; Kühne 2018). In terms of systems theory, the concept of ecosystem services can be seen as an attempt to escape the communication code of morality that is strongly present in environmental protection and nature conservation (Spanier 2006). These efforts at objectification are based on the economic code. The concept of ecosystem services can thus be understood as the effort to translate the non-economic environment into the logic of the economic system. This translation, however, may have some unintended side effects:

- Ecosystem products are only ecosystem services if people have an (economic) interest in them. At the same time, it is assumed that the products of ecosystems are always associated with added value for humans, a statement which can, however, be questioned in view of natural succession on a meadow orchard (Jax 2010; Jax 2016; Kirchhoff 2018; Kirchhoff 2019b).

- With the concept of ecosystem services, the natural environment is made available to the binary logic of economics and thus subjected to the code of having and not having. This initially excludes other codes (such as aesthetic, social recognition or ethical). The economic system does not construct the world according to these codes. The integration of 'scenic beauty', for example, does not take place via an aesthetic code ugly/beautiful, but is transformed economically, for example by the willingness to pay for the preservation of physical structures (see also Zierhofer 1998).

- The subordination of reference to society to the logic of having and not having involves a loss of adequate social reference: environmental politics, for example, is no longer political, science is no longer viewed in terms of gaining knowledge, and media communication is no longer seen in terms of current news value. Access to the world is always based on the possibility of earning money or the risk of losing money. This means responding adequately to the loss of challenges, such as regulatory policy, by formulating alternative scientific positions or by reporting on ecological damage (beyond financial damage) (Kühne 2014). The result is a reduction in the possibilities of constructing the world on the one hand or reacting to changes in the world on the other, since there is always a transformation into monetary units.

Beyond these overall social restrictions of the concept, problems also arise within the individual social subsystems through the focus on the transformation of environmental services into pecuniary relationships. In relation to the social subsystem of science, the subordination of social references involves a subordination of the social to a scientific causal logic, which, although it corresponds to the logic of macroeconomics and thus ultimately goes back to a mechanistic Newtonian view of the world (Brodbeck 1998), disregards specific social logics, such as the control of social action through the granting or withdrawal of social recognition, as well as various motives for individual action from beyond an economic schema of rational choice (Gunton/van Asperen/Basden 
et al. 2017). In this respect, Kirchhoff (2018: 18) advocates not integrating "intrinsic, non-instrumental, aesthetic, symbolic and moral values" into the ecosystem services approach.

Another major economic problem of the ecosystem services approach relates to the way in which ecosystem services are pressured (see in general Kruse 1959). In a market economy, prices are the result of supply and demand, but also of the search for substitutes, which means that - if substitution is possible and only if these are marketable goods - ecosystem services cannot be priced intertemporally. It can be assumed here that prices fall - for example when the supply of an ecosystem service increases - as a result of which the service is used to an increasing extent. This also means, however, that - if oil and gas became scarce - prices would rise on the one hand, and on the other hand, oil and gas prices could be substituted by other goods, which is not possible for essential goods such as clean air from an economic perspective alone (cf. e.g. Kühne 2004; Hansjürgens 2015).

The ecosystem services approach assumes - in the tradition of scientific thought - that ecosystems are 'real' units. If, on the other hand, a social science perspective is adopted, all systems, including ecosystems, are social constructions in the sense of an abstraction of observed material objects and their interactions. This means that not only the level of the economic valuation becomes contingent (as a result of the subjective value appreciation), but also the level of the material objects, which are combined in different (contingent) ways and can thus become the object of the valuation (cf. Kühne 2003; Kirchhoff 2018; Kirchhoff 2019a).

In terms of natural-scientific theory, another de-differentiation of the ecosystem services approach, namely the mixing of the descriptive, analytical and normative dimensions, weighs particularly heavily. The world is described as an ecosystem and the interactions of its components are investigated, at the same time the existence of the ecosystem is ascribed a normative significance; this is a classic naturalistic fallacy (cf. Hübner 2018: 40 ff.). Just because there are certain constellations of objects that are called ecosystems does not mean that they should also exist, for instance because they are quite capable of developing (cf. Berr 2018a; Berr 2018b). In this respect, the ecosystem services approach is based on normative conservatism, which prefers to define change under the mode of perception of rejection (Kühne 2005; Voigt 2009a; Voigt 2009b; Kirchhoff 2018). This normative conservatism also means that competition for suitable changes that could increase resilience, for example, is prevented (see in principle Dahrendorf 1968; Popper 1973).

\section{Conclusion and outlook}

A great merit of the ecosystem services concept can be seen in the development of a complement to moral, political and legal communication. This enables the economic system to treat 'nature' according to its own specific system code. The grounds on which moral communication can be attacked are thus reduced. After all, in recent decades the economic system has often been accused of being 'blind' to ecological issues, which has led to broad social moral condemnation. However, having started from an effort to provide arguments for the conservation of nature that go beyond the classical eigenvalue approach by focusing on an economic perspective, the approach has now reached an almost hegemonic-discursive status that makes it difficult for alternative approaches to be perceived. Not only does such a hegemonic position restrict scientific competition and thus scientific progress (cf. Popper 1973), the approach of ecosystem services itself represents a conservative-harmonistic understanding of ecology (Voigt 2009a), which assumes a harmonious coexistence of biotic and abiotic as well as social components. Even such a normative-harmonious approach systematically underestimates the productivity of conflicts (Dahrendorf 1972; Dahrendorf 1992; Kühne 2019). Ultimately, both the conservative approach and the attempt to reduce complexity of the natural environment and society with the help of a code (in the case of the ecosystem services preferably one of money) involves a social de-differentiation that is 'paid for' with the loss of (social) adaptability, since society can no longer respond to challenges in a differentiated way but only under the mode of priced services.

Nevertheless, what are the alternatives to an ecosystem services concept? A prerequisite for more appropriate management of the countless relationships between human beings and their natural environment would be, first, recognition that these relationships are so diverse and multifarious that they cannot simply be reduced to one factor. Secondly, it is essential to acknowledge that humans and the environment are not two separate worlds but different degrees of hybridity. Just as there are no more uninfluenced areas on earth (due to changes in the composition of the atmosphere), it is difficult to describe man as a unit uninfluenced by the natural environment. Thirdly, an examination of the 
manifold and hybrid relationships between humans and nature requires a spatially differentiated consideration of the processual and functional interactions between them, taking into account the respective scale transitions. This includes the superposition of antagonistic functions and processes (such as trade-offs). Fourthly, in view of the unmanageable diversity of ecosystems at the global and the regional scales as well, their different biophysical conditions, their different natural capacities, and their different resiliences and burdens, uniform global evaluation schemes for ecosystem services appear to make little sense and presumably also ignore the real requirements of landscape planning committed to the principles of sustainability. Fifthly, human-nature relationships are not static, but subject to abrupt or constant change. For example, people's expectations of their natural environment are changing. The gain in importance of 'experiences of nature' as compensation for increasing mechanisation in some regions of the world can be countered by a completely contradictory perception of nature in other regions. This, too, cannot be framed with uniform valuation standards.

In accordance with the diverse criticism of the ecosystem services approach presented in this paper, we question the sense of the attempt to reduce the diversity and hybridities in human-nature contexts to a value that is often difficult to quantify with regard to its estimation error. Instead, we believe it makes sense to choose a variety of approaches appropriate to the complexity, which is in line with IPBES principles as described by Pascual, Palomo, Adams et al. (2017). According to Pascual, Balvanera, Díaz et al. (2017: 14), "promoting different conceptualizations of value and valuation approaches is more appropriate than a deeper focus on a subset of unidimensional values (e.g. economic, biophysical, socio-cultural)" whenever possible. Thus, cultural references require a different conceptual framing (and scaling) than social, economic or ecological functions. In view of political trends towards radical decomplexation, a differentiated approach seems more appropriate than following the current tendency towards simplification.

\section{References}

Bagstad, K.J.; Semmens, D.J.; Waage, S.; Winthrop, R. (2013): A comparative assessment of decision-support tools for ecosystem services quantification and valuation. In: Ecosystem Services 5, 27-39. doi: 10.1016/j.ecoser.2013.07.004
Bastian, O.; Haase, D.; Grunewald, K. (2012): Ecosystem properties, potentials and services - The EPPS conceptual framework and an urban application example. In: Ecological Indicators 21, 7-16. doi: 10.1016/j.ecolind.2011.03.014

Bastian, O.; Schreiber, K.-F. (eds.) (1994): Analyse und ökologische Bewertung der Landschaft. Jena.

Bastian, O.; Steinhardt, U. (eds.) (2002): Development and Perspectives of Landscape Ecology. Dordrecht. doi: 10.1007/978-94-017-1237-8

Battisti, C.; Poeta, G.; Fanelli, G. (2016): An Introduction to Disturbance Ecology. A Road Map for Wildlife Management and Conservation. Dordrecht. doi: 10.1007/978-3-319-32476-0

Bennett, E.M.; Peterson, G.D.; Gordon, L.J. (2009): Understanding relationships among multiple ecosystem services. In: Ecology Letters 12, 12, 1394-1404. doi: 10.1111/j.1461-0248.2009.01387.x

Bennett, E.M.; Cramer, W.; Begossi, A.; Cundill, G.; Díaz, S.; Egoh, B.N.; Geijzendorffer, I.R.; Krug, C.B.; Lavorel, S.; Lazos, E.; Lebel, L.; Martín-López, B.; Meyfroidt, P.; Mooney, H.A.; Nel, J.L.; Pascual, U.; Payet, K.; Pérez-Harguindeguy, N.; Peterson, G.D.; Prieur-Richard, A.H.; Reyers, B.; Roebeling, P.; Seppelt, R.; Solan, M.; Tschakert, P.; Tscharntke, T.; Turner II, B.L.; Verburg, P.H.; Viglizzo, E.F.; White, P.C.L.; Woodward G. (2015): Linking biodiversity, ecosystem services, and human well-being. Three challenges for designing research for sustainability. In: Current Opinion in Environmental Sustainability 14, 76-85. doi: 10.1016/j.cosust.2015.03.007

Berr, K. (2018a): Ethische Aspekte der Energiewende. In: Kühne, O.; Weber, F. (eds.): Bausteine der Energiewende. Wiesbaden, 57-74. doi: 10.1007/978-3-658-19509-0

Berr, K. (2018b): Überlegungen zu einem proto-theoretischen Unterbau der Landschaftsarchitektur. In: Berr, K. (ed.): Landschaftsarchitekturtheorie. Aktuelle Zugänge, Perspektiven und Positionen. Wiesbaden, 123-164. doi: 10.1007/978-3-658-18838-2

Birkhofer, K.; Diehl, E.; Andersson, J.; Ekroos, J.; Früh-Müller, A.; Machnikowski, F.; Mader, V.L.; Nilsson, L.; Sasaki, K.; Rundlöf, M.; Wolters, V.; Smith, H.G. (2015): Ecosystem services current challenges and opportunities for ecological research. In: Frontiers in Ecology and Evolution 2, 87, 1-9. doi: 10.3389/ fevo.2014.00087

Boyd, J.; Banzhaf, S. (2007): What are ecosystem services? The need for standardized environmental accounting units. In: Ecological Economics 63, 2-3, 616-626. doi: 10.1016/j. ecolecon.2007.01.002

Braat, L.C.; de Groot, R. (2012): The ecosystem services agenda. Bridging the worlds of natural science and economics, conservation and development, and public and private policy. In: Ecosystem Services 1, 1, 4-15. doi: 10.1016/j. ecoser.2012.07.011

Brodbeck, K.H. (1998): Die fragwürdigen Grundlagen der Ökonomie. Eine philosophische Kritik der modernen Wirtschaftswissenschaften. Darmstadt.

Chan, K.M.A.; Satterfield, T.; Goldstein, J. (2012): Rethinking ecosystem services to better address and navigate cultural values. In: Ecological Economics 74, 8-18. doi: 10.1016/j. ecolecon.2011.11.011

Costanza, R. (ed.) (1991): Ecological economics: the science and management of sustainability. New York.

Costanza, R.; d'Arge, R.; de Groot, R.; Farber, S.; Grasso, M.; Hannon, B.; Limburg, K.; Naeem, S.; O’Neill, R.V.; Paruelo, J.; 
Raskin, R.G.; Sutton, P.; van den Belt, M. (1997): The value of the world's ecosystem services and natural capital. In: Nature 387, 6630, 253-260. doi: 10.1038/387253a0

Costanza, R.; de Groot, R.; Braat, L.; Kubiszewski, I.; Fioramonti, L.; Sutton, P.; Farber, S.; Grasso, M. (2017): Twenty years of ecosystem services. How far have we come and how far do we still need to go? In: Ecosystem Services 28, A, 1-16. doi: 10.1016/j.ecoser.2017.09.008.

Cropper, M.L.; Oates, W.E. (1992): Environmental Economics: A Survey. In: Journal of Economic Literature 30, 2, 675-740.

Dahrendorf, R. (1968): Pfade aus Utopia. Arbeiten zur Theorie und Methode der Soziologie. München.

Dahrendorf, R. (1972): Konflikt und Freiheit. Auf dem Weg zur Dienstklassengesellschaft. München.

Dahrendorf, R. (1992): Der moderne soziale Konflikt. Essay zur Politik der Freiheit. Stuttgart.

de Groot, R.S.; Wilson, M.A.; Boumans, R.M.J. (2002): A typology for the classification, description and valuation of ecosystem functions, goods and services. In: Ecological Economics 41, 3, 393-408. doi: 10.1016/S0921-8009(02)00089-7

Díaz, S.; Demissew, S.; Carabias, J.; Joly, C.; Lonsdale, M.; Ash, N.; Larigauderie, A.; Adhikari, J.R.; Arico, S.; Báldi, A.; Bartuska, A.; Baste, I.A.; Bilgin, A.; Brondizio, E.; Chan, K.M.A.; Figueroa, V.E.; Duraiappah, A.; Fischer, M.; Hill, R.; Koetz, T.; Leadley, P.; Lyver, L.; Mac, G.M.; Martin-Lopez, B.; Okumura, M.; Pacheco, D.; Pascual, U.; Pérez, E.S.; Reyers, B.; Roth, E.; Saito, O.; Scholes, R.J.; Sharma, N.; Tallis, H.; Thaman, R.; Watson, R.; Yahara, T.; Hamid, Z.A.; Akosim, C.; Al-Hafedh, Y.; Allahverdiyev, R.; Amankwah, E.; Asah, S.T.; Asfaw, Z.; Bartus, G.; Brooks, L.A.; Caillaux, J.; Dalle, G.; Darnaedi, D.; Driver, A.; Erpul, G.; Escobar-Eyzaguirre, P.; Failler, P.; Mokhtar Fouda, A.M.; Fu, B.; Gundimeda, H.; Hashimoto, S.; Homer, F.; Lavorel, S.; Lichtenstein, G.; Mala, W.A.; Mandivenyi, W.; Matczak, P.; Mbizvo, C.; Mehrdadi, M.; Metzger, J.P.; Mikissa, J.B.; Moller, H.; Mooney, H.A.; Mumby, P.; Nagendra, H.; Nesshöver, C.; Oteng-Yeboah, A.A.; Pataki, G.; Roué, M.; Rubis, J.; Schultz, M.; Smith, P.; Sumaila, R.; Takeuchi, K.; Thomas, S.; Verma, M.; Yeo-Chang, Y.; Zlatanova, D. (2015): The IPBES Conceptual Framework - connecting nature and people. In: Current Opinion in Environmental Sustainability 14, 1-16. doi: 10.1016/j.cosust.2014.11.002.

Donovan, G.H.; Brown, T.C. (2007): Be careful what you wish for: the legacy of Smokey Bear. In: Frontiers in Ecology and the Environment 5, 2, 73-79.

Dunn, R.R. (2010): Global Mapping of Ecosystem Disservices: The Unspoken Reality that Nature Sometimes Kills us. In: Biotropica 42, 5, 555-557. doi: 10.1111/j.1744-7429.2010.00698.x

Fish, R.; Church, A.; Winter, M. (2016): Conceptualising cultural ecosystem services: A novel framework for research and critical engagement. In: Ecosystem Services 21, B, 208-217. doi: 10.1016/j.ecoser.2016.09.002

García-Nieto, A.P.; García-Llorente, M.; Iniesta-Arandia, I.; MartinLópez, B. (2013): Mapping forest ecosystem services: From providing units to beneficiaries. In: Ecosystem Services 4, 126138. doi: 10.1016/j.ecoser.2013.03.003

Gómez-Baggethun, E.; Ruiz-Pérez, M. (2011): Economic valuation and the commodification of ecosystem services. In: Progress in Physical Geography 35, 5, 613-628. doi: 10.1177/0309133311421708
Grunewald,K.;BastianO.(eds.)(2013a):Ökosystemdienstleistungen. Konzept, Methoden und Fallbeispiele. Berlin.

Grunewald, K.; Bastian, O. (2013b): Ökosystemleistungen (ÖSD) - mehr als ein Modewort? In: Grunewald, K.; Bastian O. (eds.): Ökosystemdienstleistungen. Konzept, Methoden und Fallbeispiele. Berlin, 1-11.

Grunewald, K.; Bastian, O. (2013c): Schlüsselbegriffe. In: Grunewald, K.; Bastian O. (eds.): Ökosystemdienstleistungen. Konzept, Methoden und Fallbeispiele. Berlin, 14-36.

Grunewald, K.; Bastian, O. (2014): Konzept und Rahmenmethodik zur Analyse und Bewertung von Ökosystemdienstleistungen (ÖSD). In: Grunewald, K.; Bastian, O.; Drozdov, A.; Grabovsky, V. (eds.): Erfassung und Bewertung von Ökosystemdienstleistungen (ÖSD) - Erfahrungen, insbesondere aus Deutschland und Russland. Bonn, 36-48. = BfN-Skripten 373 .

Grunewald, K.; Bastian, O.; Syrbe, R.-U. (2013): Raum-ZeitAspekte von ÖSD. In: Grunewald, K.; Bastian O. (eds.) (2013): Ökosystemdienstleistungen. Konzept, Methoden und Fallbeispiele. Berlin, 56-69.

Gunton, R.M.; van Asperen, E.N.; Basden, A.; Bookless, D.; Araya, Y.; Hanson, D.R.; Goddard, M.A.; Otieno, G.; Jones, G.O. (2017): Beyond Ecosystem Services: Valuing the Invaluable. In: Trends in Ecology and Evolution 32, 4, 249-257. doi: 10.1016/j.tree.2017.01.002

Haase, G. (ed.) (1991): Naturraumerkundung und Landnutzung. Geochorologische Verfahren zur Analyse, Kartierung und Bewertung von Naturräumen. Berlin. = Beiträge zur Geographie 34/1.

Haines-Young, R.; Potschin, M. (2009): Methodologies for defining and assessing ecosystem services. Nottingham. = CEM Report 14.

Haines-Young, R.; Potschin, M. (2010): The links between biodiversity, ecosystem services and human well-being. In: Raffaelli, D.G.; Frid, C.L.J. (eds.): Ecosystem Ecology: A New Synthesis. Cambridge, 110-139. doi:10.1017/ CBO9780511750458.007

Haines-Young, R.; Potschin, M. (2018): Common International Classification of Ecosystem Services (CICES) V5.1. Guidance on the Application of the Revised Structure. https://cices.eu/ content/uploads/sites/8/2018/01/Guidance-V51-01012018.pdf (16.08.2019).

Hansjürgens, B. (2015): Zur Neuen Ökonomie der Natur: Kritik und Gegenkritik. In: Wirtschaftsdienst 95, 4, 284-291.

Hansjürgens, B.; Schröter-Schlaack, C. (2012): Die ökonomische Bedeutung der Natur. In: Hansjürgens, B.; Neßhöver, C.; Schniewind, I. (eds.): Der Nutzen von Ökonomie und Ökosystemleistungen für die Naturschutzpraxis. Workshop I: Einführung und Grundlagen. Bonn, 16-21. = BfN-Skripten 318.

Howe, C.; Suich, H.; Vira, B.; Mace, G.M. (2014): Creating win-wins from trade-offs? Ecosystem services for human well-being: A meta-analysis of ecosystem service trade-offs and synergies in the real world. In: Global Environmental Change 28, 263275. doi: 10.1016/j.gloenvcha.2014.07.005

Hübner, D. (2018): Einführung in die philosophische Ethik. Göttingen.

Hutto, R.L. (2008): The ecological importance of severe wildfires: Some like it hot. In: Ecological Applications 18, 8, 1827-1834. Jax, K. (2010): Ecosystem Functioning. Cambridge. 
Jax, K. (2016): Ökologie. In: Ott, K.; Dierks, J.; Voget-Kleschin, L. (eds.): Handbuch Umweltethik. Stuttgart, 37-43.

Kirchhoff, T. (2012): Pivotal cultural values of nature cannot be integrated into the ecosystem services framework. In: Proceedings of the National Academy of Sciences of the United States of America 109, 46, E3146-E3146. doi: 10.1073/ pnas. 1212409109

Kirchhoff, T. (2018): „Kulturelle Ökosystemdienstleistungen“: Eine begriffliche und methodische Kritik. Freiburg.

Kirchhoff, T. (2019a): Ökosystemdienstleistungen. In: Kühne, O.; Weber, F.; Berr, K.; Jenal, C. (eds.): Handbuch Landschaft. Wiesbaden, 807-822. doi: 10.1007/978-3-658-25746-0_65

Kirchhoff, T. (2019b): Abandoning the Concept of Cultural Ecosystem Services, or Against Natural-Scientific Imperialism. In: BioScience 69, 3, 220-227. doi: 10.1093/biosci/biz007

Kosoy, N.; Corbera, E. (2010): Payments for ecosystem services as commodity fetishism. In: Ecological Economics 69, 6, 12281236. doi: 10.1016/j.ecolecon.2009.11.002

Kruse, A. (1959): Geschichte der volkswirtschaftlichen Theorien. Berlin.

Kubiszewski, I.; Costanza, R.; Anderson, S.; Sutton, P. (2017): The future value of ecosystem services. Global scenarios and national implications. In: Ecosystem Services 26, A, 289-301. doi: 10.1016/j.ecoser.2017.05.004

Kühne, O. (2003): Umwelt und Transformation in Polen. Eine kybernetisch-systemtheoretische Analyse. Mainz. = Mainzer Geographische Studien 51.

Kühne, O. (2004): Monetarisierung der Umwelt: Chancen und Probleme aus raumwissenschaftlich-systemtheoretischer Perspektive. Wien. $=$ Beiträge zur Kritischen Geographie 3.

Kühne, O. (2005): Landschaft als Konstrukt und die Fragwürdigkeit der Grundlagen der konservierenden Landschaftserhaltung - eine konstruktivistisch-systemtheoretische Betrachtung. Wien. $=$ Beiträge zur Kritischen Geographie 4.

Kühne, O. (2014): Das Konzept der Ökosystemdienstleistungen als Ausdruck ökologischer Kommunikation. Betrachtungen aus der Perspektive Luhmannscher Systemtheorie. In: Naturschutz und Landschaftsplanung 46, 1, 17-22.

Kühne, O. (2018): Die Moralisierung von Landschaft - Überlegungen zu einer problematischen Kommunikation aus Sicht der Luhmannschen Systemtheorie. In: Hennecke, S.; Kegler, H.; Klaczynski, K.; Münderlein, D. (eds.): Diedrich Bruns wird gelehrt haben. Eine Festschrift. Kassel, 115-121.

Kühne, O. (2019): Die Produktivität von Landschaftskonflikten - Möglichkeiten und Grenzen auf Grundlage der Konflikttheorie Ralf Dahrendorfs. In: Berr, K.; Jenal, C. (eds.): Landschaftskonflikte. Wiesbaden, 37-49. doi: 10.1007/978-3658-22325-0

La Notte, A.; D’Amato, D.; Mäkinen, H.; Paracchini, M.L.; Liquete, C.; Egoh, B.; Geneletti, D.; Crossman, N.D. (2017): Ecosystem services classification: A systems ecology perspective of the cascade framework. In: Ecological Indicators 74, 392-402. doi: 10.1016/j.ecolind.2016.11.030

Lautenbach, S.; Mupepele, A.-C.; Dormann, C.F.; Lee, H.; Schmidt, S.; Scholte, S.S.K.; Seppelt, R.; van Teeffelen, A.J.A.; Verhagen, W.; Volk, M. (2019): Blind spots in ecosystem services research and challenges for implementation. In: Regional Environmental Change. doi: 10.1007/s10113-0181457-9
Lavorel, S.; Bayer, A.; Bondeau, A.; Lautenbach, S.; Ruiz-Frau, A.; Schulp, N.; Seppelt, R.; Verburg, P.; van Teeffelen, A.; Vannier, C.; Arneth, A.; Cramer, W.; Marba, N. (2017): Pathways to bridge the biophysical realism gap in ecosystem services mapping approaches. In: Ecological Indicators 74, 241-260. doi: 10.1016/j.ecolind.2016.11.015

Lee, C. (2004): Kritik der neoklassischen Umweltökonomik. Über die (Un-)Möglichkeit einer pareto-effizienten Umweltsteuer. Frankfurt am Main. = Institutionelle und Sozial-Ökonomie 13.

Leibenath, M. (2017): Ecosystem services and neoliberal governmentality - German style. In: Land Use Policy 64, 307316. doi: 10.1016/j.landusepol.2017.02.037

Lescourret, F.; Magda, D.; Richard, G.; Adam-Blondon, A.-F.; Bardy, M.; Baudry, J.; Doussan, I.; Dumont, B.; Lefèvre, F.; Litrico, I.; Martin-Clouaire, R.; Montuelle, B.; Pellerin, S.; Plantegenest, M.; Tancoigne, E.; Thomas, A.; Guyomard, H.; Soussana, J.-F. (2015): A social-ecological approach to managing multiple agro-ecosystem services. In: Current Opinion in Environmental Sustainability 14, 68-75. doi: 10.1016/j.cosust.2015.04.001

Liu, J.; Yang, W.; Li, S. (2016): Framing ecosystem services in the telecoupled Anthropocene. In: Frontiers in Ecology and the Environment 14, 1, 27-36. doi: 10.1002/16-0188.1

López-Hoffman, L.; Varady, R.G.; Flessa, K.W.; Balvanera, P. (2010): Ecosystem services across borders: a framework for transboundary conservation policy. In: Frontiers in Ecology and the Environment 8, 2, 84-91. doi: 10.1890/070216

Luhmann, N. (1980): Gesellschaftsstruktur und Semantik. Studien zur Wissenssoziologie der modernen Gesellschaft. Frankfurt am Main.

Luhmann, N. (1984): Soziale Systeme. Grundriß einer allgemeinen Theorie. Frankfurt am Main.

Luhmann, N. (1986): Ökologische Kommunikation. Kann die moderne Gesellschaft sich auf ökologische Gefährdungen einstellen? Opladen.

Luhmann, N. (1993): Die Moral des Risikos und das Risiko der Moral. In: Bechmann, G. (ed.): Risiko und Gesellschaft. Grundlagen und Ergebnisse interdisziplinärer Risikoforschung. Opladen, 327-338.

Luhmann, N. (2002): Einführung in die Systemtheorie. Heidelberg. Lyytimäki, J.; Sipilä, M. (2009): Hopping on one leg - The challenge of ecosystem disservices for urban green management. In: Urban Forestry and Urban Greening 8, 4, 309-315. doi: 10.1016/j.ufug.2009.09.003

Marks, R.; Müller, M.J.; Leser, H.; Klink, H.-J. (1989): Anleitung zur Bewertung des Leistungsvermögens des Landschaftshaushaltes (BA LVL). Trier. = Forschungen zur deutschen Landeskunde 229.

Martinez-Harms, M.J.; Bryan, B.A.; Balvanera, P.; Law, L.A.; Rhodes, J.R.; Possingham, H.P.; Wilson, K.A. (2015): Making decisions for managing ecosystem services. In: Biological Conservation 184, 229-238. doi: 10.1016/j.biocon.2015.01.024.

MEA - Millennium Ecosystem Assessment (2005): Ecosystems and Human Well-Being: General Synthesis. Washington.

Montagne-Huck, C.; Brunette, M. (2017): Economic Analysis of Natural Forest Disturbances: $\mathrm{A}$ Century of Research. Nancy. = Document de travail No. 2017-08, AgroParisTech Laboratoire d'Economie Forestière.

Mosimann, T.; Köhler, I.; Poppe, I. (2001): Entwicklung prozessual begründeter landschaftsökologischer Leitbilder für funktional 
vielfältige Landschaften. In: Berichte zur deutschen Landeskunde 75, 1, 33-66.

Müller, F.; Burkhard, B. (2012): The indicator side of ecosystem services. In: Ecosystem Services 1, 1, 26-30. doi: 10.1016/j. ecoser.2012.06.001

Nelson, E.; Mendoza, G.; Regetz, J.; Polasky, S.; Tallis, H.; Cameron, D.R.; Chan, K.M.A.; Daily, G.C.; Goldstein, J.; Kareiva, P.M.; Lonsdorf, E.; Naidoo, R.; Ricketts, T.H.; Shaw M.R. (2009): Modeling multiple ecosystem services, biodiversity conservation, commodity production, and tradeoffs at landscape scales. In: Frontiers in Ecology and the Environment 7, 1, 4-11. doi: 10.1890/080023

Parsons, T. (1951): The Social System. Glencoe.

Pascual, U.; Balvanera, P.; Díaz, S.; Pataki, G.; Roth, E.; Stenseke, M.; Watson, R.T.; Dessane, E.B.; Islar, M.; Kelemen, E.; Maris, V.; Quaas, M.; Subramanian, S.M.; Wittmer, H.; Adlan, A.; Ahn, S.E.; Al-Hafedh, Y.S.; Amankwah, E.; Asah, S.T.; Berry, P.; Bilgin, A.; Breslow, S.J.; Bullock, C.; Cáceres, D.; DalyHassen, H.; Figueroa, E.; Golden, C.D.; Gómez-Baggethun, E.; González-Jiménez, D.; Houdet, J.; Keune, H.; Kumar, R.; Ma, K.; May, P.H.; Mead, A.; O'Farrell, P.; Pandit, R.; Pengue, W.; Pichis-Madruga, R.; Popa, F.; Preston, S.; PachecoBalanza, D.; Saarikoski, H.; Strassburg, B.B.; van den Belt, M.; Verma, M.; Wickson, F.; Yagi, N. (2017): Valuing nature's contributions to people: the IPBES approach. In: Current Opinion in Environmental Sustainability 26-27, 7-16. doi: 10.1016/j.cosust.2016.12.006

Pascual, U.; Palomo, I.; Adams, W.M.; Chan, K.M.A.; Daw, T.M.; Garmendia, E.; Gómez-Baggethun, E.; de Groot, R.S.; Mace, G.M.; Martín-López, B.; Phelps, J. (2017): Off-stage ecosystem service burdens: A blind spot for global sustainability. In: Environmental Research Letters 12, 7, 075001. doi: 10.1088/1748-9326/aa7392.

Popper, K.R. (1973): Objektive Erkenntnis. Ein evolutionärer Entwurf. Hamburg.

Potschin-Young, M.; Haines-Young, R.; Görg, C.; Heink, U.; Jax, K.; Schleyer, C. (2018): Understanding the role of conceptual frameworks. Reading the ecosystem service cascade. In: Ecosystem Services 29, C, 428-440. doi: 10.1016/j. ecoser.2017.05.015.

Rieb, J.T.; Chaplin-Kramer, R.; Daily, G.C.; Armsworth, P.R.; Böhning-Gaese, K.; Bonn, A.; Cumming, G.S.; Eigenbrod, F.; Grimm, V.; Jackson, B.M.; Marques, A.; Pattanayak, S.K.; Pereira, H.M.; Peterson, G.D.; Ricketts, T.H.; Robinson, B.E.; Schröter, M.; Schulte, L.A.; Seppelt, R.; Turner, M.G.; Bennett, E.M. (2017): When, Where, and How Nature Matters for Ecosystem Services: Challenges for the Next Generation of Ecosystem Service Models. In: BioScience 67, 9, 820-833. doi:10.1093/biosci/bix075

Rogers, P. (1996): Disturbance Ecology and Forest Management: a Review of the Literature. Ogden.

Sandbrook, C.G.; Burgess, N.D. (2015): Biodiversity and ecosystem services: not all positive. In: Ecosystem Services 12, doi: 10.1016/j.ecoser.2014.12.006

Schröter, M.; Koellner, T.; Alkemade, R.; Arnhold, S.; Bagstad, K.J.; Erb, K.-H.; Frank, K.; Kastner, T.; Kissinger, M.; Liu, J.; LópezHoffman, L.; Maes, J.; Marques, A.; Martín-López, B.; Meyer, C.; Schulp, C.J.E.; Thober, J.; Wolff, S.; Bonn, A. (2018): Interregional flows of ecosystem services: Concepts, typology and four cases. In: Ecosystem Services 31, B, 231-241. doi: 10.1016/j.ecoser.2018.02.003

Schröter, M.; van der Zanden, E.H.; van Oudenhoven, A.P.E.; Remme, R.P.; Serna-Chavez, H.M.; de Groot, R.S.; Opdam, P. (2014): Ecosystem Services as a Contested Concept. A Synthesis of Critique and Counter-Arguments. In: Conservation Letters 7, 6, 514-523. doi: 10.1111/conl.12091.

Seidl, R.; Thom, D.; Kautz, M.; Martin-Benito, D.; Peltoniemi, M.; Vacchiano, G.; Wild, J.; Ascoli, D.; Petr, M.; Honkaniemi, J.; Lexer, M.J.; Trotsiuk, V.; Mairota, P.; Svoboda, M.; Fabrika, M.; Nagel, T.A.; Reyer, C.P.O. (2017): Forest disturbances under climate change. In: Nature Climate Change 7, 395-402. doi: 10.1038/nclimate3303

Seppelt, R.; Dormann, C.F.; Eppink, F.V.; Lautenbach, S.; Schmidt, S. (2011): A quantitative review of ecosystem service studies. Approaches, shortcomings and the road ahead. In: Journal of Applied Ecology 48, 4, 630-636. doi: 10.1111/j.13652664.2010.01952.x

Shapiro, J.; Báldi, A. (2014): Accurate accounting. How to balance ecosystem services and disservices. In: Ecosystem Services 7, 201-202. doi: 10.1016/j.ecoser.2014.01.002

Smeets, E.; Weterings, R. (1999): Environmental indicators: typology and overview. Copenhagen. = European Environment Agency, Technical Report 25.

Spanier, H. (2006): Pathos der Nachhaltigkeit. Von der Schwierigkeit, „Nachhaltigkeit“ zu kommunizieren. In: Stadt+Grün 55, 12 , 26-33.

Techen, A.-K.; Helming, K. (2017): Pressures on soil functions from soil management in Germany. A foresight review. In: Agronomy for Sustainable Development 37, 64. doi: 10.1007/ s13593-017-0473-3

TEEB - The Economics of Ecosystems and Biodiversity (2010): The Economics of Ecosystems and Biodiversity. Ecological and Economic Foundations. London.

UBA - Umweltbundesamt (2013): Globale Landflächen und Biomasse nachhaltig und ressourcenschonend nutzen. Dessau-Roßlau.

UBA - Umweltbundesamt (2018): Daten zur Umwelt: Umwelt und Landwirtschaft. Dessau-Roßlau.

Voigt, A. (2009a): „Wie sie ein Ganzes bilden“ - analoge Deutungsmuster in ökologischen Theorien und politischen Philosophien der Vergesellschaftung. In: Kirchhoff, T.; Trepl, L. (eds.): Vieldeutige Natur. Landschaft, Wildnis und Ökosystem als kulturgeschichtliche Phänomene. Bielefeld, 331-348.

Voigt, A. (2009b): Die Konstruktion der Natur. Ökologische Theorien und politische Philosophien der Vergesellschaftung. München. = Sozialgeographische Bibliothek 12.

Wood, S.L.R.; Jones, S.K.; Johnson, J.A.; Brauman, K.A.; ChaplinKramer, R.; Fremier, A.; Girvetz, E.; Gordon, L.J.; Kappel, C.V.; Mandle, L.; Mulligan, M.; O’Farrell, P.; Smith, W.K.; Willemen, L.; Zhang, W.; DeClerck, F.A. (2018): Distilling the role of ecosystem services in the Sustainable Development Goals. In: Ecosystem Services 29, A, 70-82. doi: 10.1016/j. ecoser.2017.10.010

Zierhofer,W.(1998):DasWaldsterbeninderInformationsgesellschaft. Zur Anwendung der sprachpragmatischen Handlungstheorie in Sozialgeographie und Humanökologie. In: Geographica Helvetica 53, 2, 60-68. doi: 10.5194/gh-53-60-1998 